\title{
Simulasi Ektraksi Citra Wajah dengan Deskriptor Global Direct Fractional-Step Linear Discriminant Analysis (DF-LDA) untuk Pengenalan Wajah
}

\author{
Ikuthen Gabriel Barus ${ }^{1}$, Riko Arlando Saragih ${ }^{2}$ \\ Jurusan Teknik Elektro, \\ Fakultas Teknik, \\ Universitas Kristen Maranatha, Bandung \\ ${ }^{1}$ sibayakjamburlige@ymail.com, 2riko_saragih@yahoo.com
}

\begin{abstract}
Ringkasan
Tulisan ini memaparkan simulasi ekstraksi citra wajah secara global dengan menggunakan salah satu teknik Linear Discriminant Analysis (LDA), yaitu Direct Fractional-Step LDA (DFLDA) untuk pengenalan wajah. Tujuan tulisan ini adalah untuk mengevaluasi unjuk kerja teknik ini terhadap masalah small sample size (SSS) yang sering muncul di dalam pengenalan wajah. Pada dasarnya teknik berbasis LDA ini (DF-LDA) merupakan kombinasi dari teknik D-LDA dan F-LDA, dimana untuk merepresentasikan citra wajah secara global secara efisien dapat ditambahkan sebuah fungsi pembobot (weighting function) dengan bertahap secara langsung dan fraksional pada proses LDA. Proses pencocokan dilakukan dengan mencari jarak Euclidean minimum antara ciri citra wajah uji terhadap ciri citra wajah latih yang terdapat di dalam database. Dari hasil simulasi untuk Database Face Recognition Data dan Database Mahasiswa Maranatha diperoleh akurasi pengenalan wajah yang lebih baik untuk kondisi jumlah citra wajah satu per orang di dalam proses pelatihan jika database wajah diproses secara terpisah.
\end{abstract}

Kata kunci: akurasi, ciri, citra wajah, DF-LDA, small sample size (SSS)

\section{Pendahuluan}

Akurasi pengenalan wajah sangat ditentukan oleh deskripsi/representasi citra wajah dan desain pengklasifikasi (classifier design). Tujuan dari representasi citra wajah adalah untuk memperoleh sekumpulan feature (ciri khas) dari sebuah citra wajah yang dapat meminimalkan variasi intra-class (misal: antar citra wajah yang berbeda tetapi dari individu yang sama), sekaligus memaksimalkan variasi inter-class (misal: antar citra wajah individu yang berbeda). Selain itu, deskriptor citra wajah juga diharapkan robust terhadap perubahan pencahayaan, pose, ekspresi, umur, jenis kelamin, ras, dan lain-lain, serta mudah untuk mengekstraksinya (memperolehnya) dari sebuah citra wajah. Hal yang menjadi catatan penting dalam merepresentasikan citra wajah adalah jika representasi citra wajah yang diperoleh tidak cukup diskriminatif, bahkan pengklasifikasi (classifier) yang paling canggih sekalipun akan gagal untuk melakukan peran untuk pengenalan wajah. Oleh karena itu, sangat penting untuk menentukan dengan hati - hati 
representasi wajah yang akan diambil ketika merancang sebuah sistem pengenalan wajah [1].

Secara garis besar, deskriptor citra wajah dapat dibagi dua, yaitu deskriptor ciriglobal (global-feature descriptor) dan deskriptor ciri-lokal (local-feature descriptor). Deskriptor ciri-global diperoleh dengan memproses keseluruhan citra wajah (integral/whole face image) secara langsung untuk memperoleh informasi penting dari sebuah citra wajah. Sedangkan deskriptor ciri-lokal biasanya diperoleh berdasarkan esktraksi ciri dari komponen/wilayah/blok wajah tertentu. Di dalam tulisan ini ekstraksi ciri citra wajah dilakukan secara global berbasis teknik LDA, yaitu DF-LDA.

Tulisan ini berisi hal-hal sebagai berikut. Pada bagian 2 dibahas tentang gambaran umum sistem pengenalan wajah yang akan disimulasikan, bagian 3 dibahas teknik deteksi wajah menggunakan algoritma Local Successive Mean Quantization Transform (Local SMQT), bagian 4 dibahas tentang ektraksi ciri citra wajah secara global dengan teknik DF-LDA, bagian 5 dibahas tentang hasil simulasi dan analisis, dan bagian 6 berisi kesimpulan dari tulisan ini.

\section{Gambaran Sistem Pengenalan Wajah yang Akan Disimulasikan}

Face recognition atau pengenalan wajah adalah salah satu teknik identifikasi teknologi biometrik, dengan menggunakan wajah individu yang bersangkutan sebagai sumber parameter utamanya. Secara garis besar proses sistem pengenalan wajah terdiri dari tiga proses utama, yaitu proses deteksi wajah, proses ektraksi ciri citra wajah, dan proses identifikasi (Gambar 1) [2].

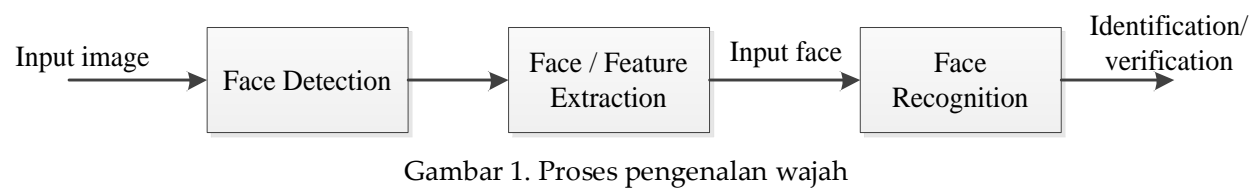

\section{Local Successive Mean Quantization Transform (Local SMQT)}

Deteksi wajah adalah sebuah proses awal dari sebuah sistem pengenalan wajah. Tujuan dari deteksi wajah adalah untuk memeriksa apakah ada citra wajah (face image) di dalam sebuah citra. Teknik deteksi wajah yang digunakan dalam tulisan ini adalah Local SMQT.

Teknik SMQT menggunakan pendekatan yang menunjukkan suatu struktur otomatis untuk mendapatkan informasi [3]. Teknik ini akan digunakan pada area lokal suatu citra untuk memilih ciri yang tidak terpengaruh terhadap pencahayaan. Area lokal dapat didefenisikan dengan berbagai cara. Contoh, suatu metode langsung adalah dengan membagi-bagi suatu citra menjadi blok-blok dengan ukuran yang sudah ditentukan sebelumnya. Cara lain dapat dilakukan dengan cara memilih nilai-nilai dengan menyisipkan titik-titik pada suatu lingkaran dengan suatu jarak dari titik yang sudah ditentukan. Walaupun demikian, sesaat sesudah area lokal ditentukan, maka hal ini merupakan suatu himpunan nilai-nilai piksel. Misalkan $x$ adalah satu piksel dan $D(x)$ adalah suatu himpunan dengan $|D(x)|=D$ piksel dari suatu area lokal pada sebuah citra. Misalkan transformasi $S M Q T$ dari area lokal adalah sebagai berikut:

$$
S M Q T_{L}: D(x) \rightarrow M(x)
$$


yang akan menghasilkan suatu himpunan nilai yang baru. Fungsi $S M Q T_{L}$ dapat dideskripsikan oleh pohon biner yang simpul-simpulnya berasal dari proses Mean Quantization Unit (MQU).

Mean Quantization Unit (MQU) terdiri dari tiga langkah proses utama, yaitu perhitungan rata - rata (mean), kuantisasi, dan pembagian himpunan input [4]. Langkah pertama dari $M Q U$ adalah menemukan rata-rata dari data, dinyatakan oleh $\bar{V}(x)$, sebagai berikut:

$$
\bar{V}(x)=\frac{1}{|D|} \sum_{x \in D} V(x)
$$

Langkah kedua menggunakan nilai rata-rata tersebut untuk mengkuantisasi nilai-nilai dari data point menjadi $\{0,1\}$. Asumsikan suatu fungsi perbandingan yang didefinisikan sebagai berikut:

$$
\xi(V(y), \bar{V}(x))= \begin{cases}1, \text { jika } V(y)>\bar{V}(x) \\ 0 & \text { untuk } x \text { lainnya }\end{cases}
$$

Dan dengan mengasumsikan П menyatakan suatu himpunan berurutan, maka :

$$
U(x)=\prod_{y \in D} \xi(V(y), \bar{V}(x))
$$

$U(x)$ pada Persamaan (4) merupakan himpunan rata-rata yang sudah terkuantisasi. Himpunan $U(x)$ adalah keluaran utama dari suatu MQU. Langkah ketiga adalah membagi himpunan masukan menjadi dua sub himpunan, yaitu $D_{0}(x)$ dan $D_{1}(x) . D_{0}(x)$ akan menyebar ke kiri, sedangkan $D_{1}(x)$ akan menyebar ke kanan pada pohon biner, seperti diilustrasikan di dalam Gambar 2.

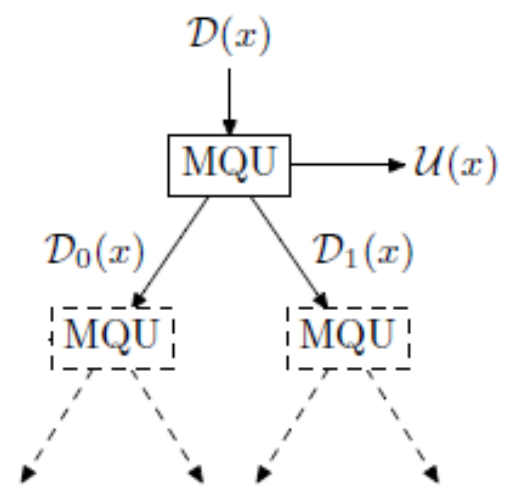

Gambar 2. Operasi dari Mean Quantization Unit (MQU)

\section{Ekstraksi Ciri Citra Wajah dengan Teknik DF-LDA}

Ekstraksi ciri citra wajah dilakukan untuk mengambil data yang efektif yang berguna untuk memisahkan antar citra wajah dan antar orang serta diharapkan cukup stabil untuk bermacam pengaruh, baik geometrik dan fotometrik. Untuk menentukan identitas citra wajah dilakukan dengan cara mencari jarak Euclidean minimum antara ciri citra 
wajah uji terhadap ciri citra wajah latih yang telah tersimpan sebagai database mewakili citra wajah.

Untuk aplikasi pengenalan wajah, LDA merupakan sebuah teknik untuk melakukan klasifikasi secara supervised [1]. Karena representasi citra wajah dalam sebuah subruang (subspace) tidak selalu linier, maka hasil pengenalan menjadi tidak akurat (terdegradasi) karena pengaruh variasi pose atau pencahayaan. Dalam pengenalan wajah, hal ini berarti bahwa variasi within-class lebih besar daripada variasi between-class. Artinya, citra wajah orang yang sama dapat dikenali sebagai orang lain jika variasi citra wajah orang tersebut cukup besar sebagai akibat pengaruh pose atau pencahayaan.

Untuk memecahkan permasalahan yang berhubungan dengan klasifikasi pola, pada umumnya digunakan teknik berbasis LDA, dimana langkah awal adalah merepresentasi objek berdimensi rendah secara optimal dengan fokus pada ekstraksi ciri yang paling diskriminan, sementara hal ini sebenarnya hanya tepat untuk rekonstruksi objek $[5,6,7,8]$. Sebagai akibatnya, kinerja klasifikasi LDA sering mengalami penurunan karena kriteria pemisahan tersebut tidak berkaitan secara langsung dengan akurasi klasifikasi di ruang output [9].

Sebuah solusi untuk mengatasi permasalahan ini adalah memperkenalkan fungsi pembobotan terhadap LDA pada kelas objek yang lebih dekat atau kelas yang sama dalam ruang output, tetapi masih dapat berpotensi menimbulkan kesalahan klasifikasi, sehingga pemberian bobot lebih diprioritaskan di ruang input. Alternatif lain dari teknik LDA, yaitu fractional-step LDA (F-LDA), dimana pengurangan dimensi ini dilakukan pada beberapa langkah pemecahan kecil yang memungkinkan untuk jarak yang relevan supaya pembobotannya lebih akurat [9]. Meskipun metode ini telah berhasil diuji pada pola berdimensi rendah $(\mathrm{D} \leq 5)$, tetapi metode ini tidak dapat diterapkan secara langsung terhadap pola berdimensi tinggi, karena terdapat dua faktor yang mempengaruhinya, yaitu tingkat kesulitan komputasi dekomposisi eigen dari matriks ruang citra berdimensi tinggi dan dimensi matriks sebaran yang mengecil akibat persoalan small sample size (SSS) yang sering ditemui pada sistem pengenalan wajah, yaitu jumlah sampel pelatihan lebih kecil daripada dimensi sampel yang digunakan [6,7,8]. Salah satu solusi untuk memecahkan persoalan SSS adalah menggunakan sebuah solusi tanpa melakukan pemisahan terhadap objek, yang disebut sebagai teknik direct LDA (D-LDA) [7].

Teknik DF-LDA merupakan teknik yang dikembangkan oleh Juwei Lu dkk [5]. Teknik ini mendeskripsikan citra wajah secara efisien dengan menambahkan sebuah fungsi pembobot (weighting function) secara langsung dan bertahap secara fraksional (fractional-step) pada proses LDA [9]. Tujuannya adalah untuk meningkatkan kemampuan memisahkan (separability) pada tahap pengenalan (jika terdapat kemiripan wajah) sehingga mengurangi kesalahan klasifikasi. Matriks proyeksi akan memaksimalkan rasio antara matriks sebaran antar-kelas (between-class scatter matrix) dengan matriks sebaran dalam-kelas (within-class scatter matrix), sehingga mampu untuk memisahkan citra dari kelas-kelas yang berbeda secara optimal [10]. Dengan kata lain, teknik DF-LDA mampu untuk mengelompokkan citra wajah yang berasal dari kelas yang sama dan memisahkan citra wajah dari kelas yang berbeda secara optimal melalui menentukan matriks proyeksi dari training set yang menghasilkan suatu matriks proyeksi yang maksimal. Matriks ini diperoleh dengan memaksimalkan matriks sebaran total (total scatter matrix) terhadap seluruh gambar dari sebuah citra berdimensi rendah [10]. 
Teknik DF-LDA merupakan kombinasi dari metode D-LDA dan F-LDA, yang secara bersamaan dapat mengatasi kelemahan dan keterbatasan dari kedua metode tersebut [5]. Dengan menggabungkan kedua teknik ini, pada tahap D-LDA, data diproses langsung di ruang input citra asli berdimensi tinggi untuk menghindari hilangnya informasi penting yang diskriminatif dengan mula-mula memperkecil dimensi ruang input cira asli, tetapi subruang SSS yang mengandung ciri yang paling yang diskriminatif akan dipertahankan. Teknik D-LDA di sini dikembangkan dengan memanfaatkan kriteria Fisher yang dimodifikasi untuk menghindari timbulnya masalah sebagai akibat dari nilai eigen yang bernilai nol dari matriks sebaran dalam-kelas [7]. Langkah selanjutnya, yaitu F-LDA, adalah dengan memasukkan suatu fungsi bobot untuk melakukan reorientasi subruang SSS secara acak, sehingga menghasilkan satu set diskriminan fitur yang optimal untuk merepresentasikan citra wajah.

Misal training set terdiri dari beberapa kelas $\left(C_{i}\right)$ yang masing-masing kelasnya mewakili identitas satu individu. Tiap-tiap kelas terdiri dari beberapa citra wajah latih $\left(L_{i}\right)$ yang menggambarkan kondisi yang berbeda, seperti perbedaan pose, pencahayaan dan lain-lain. $L$ adalah jumlah kelas citra latih. Perhitungan DF-LDA dilakukan dengan langkah-langkah sebagai berikut:

1. Ubah setiap citra wajah yang berupa matriks di training set menjadi vektor kolom $\left(\Gamma_{n}\right)$ dan setiap vektor kolom dari semua citra disusun menjadi satu matriks.

$$
\Gamma_{\mathrm{n}}=\left[\Gamma_{1}, \Gamma_{2}, \Gamma_{3}, \ldots \ldots \Gamma_{M}\right]
$$

2. Hitung citra wajah rata-rata dari semua citra latih dan citra wajah rata-rata dari setiap kelas citra latih.

$$
\begin{gathered}
\bar{z}=\frac{1}{N} \sum_{i=1}^{C} \sum_{j=1}^{C_{i}} z_{i j} \\
\bar{z}_{i}=\frac{1}{C_{i}} \sum_{j=1}^{C_{i}} z_{i j}
\end{gathered}
$$

3. Hitung selisih setiap citra latih dengan citra rata-rata

$$
z_{i}=\Gamma_{i}-\bar{z}
$$

4. Hitung matriks sebaran antar-kelas dan matriks sebaran dalam-kelas

$$
\begin{gathered}
\hat{S}_{B T W}=\sum_{i=1}^{C} \phi_{i} \phi_{i}^{T}=\Phi_{b} \Phi_{b}^{T} \\
\phi_{i}=\left(\frac{L_{i}}{L}\right)^{\frac{1}{2}} \sum_{j=1}^{C}\left(w\left(d_{i j}\right)\right)^{\frac{1}{2}}\left(\bar{z}_{i}-\bar{z}_{j}\right) \\
S_{W T H}=\frac{1}{N} \sum_{i=1}^{C} \sum_{j=1}^{C_{i}}\left(z_{i j}-\bar{z}_{i}\right)\left(z_{i j}-\bar{z}_{i}\right)^{T}=\Phi_{w} \Phi_{w}^{T}
\end{gathered}
$$

5. Hitung nilai eigen $\left(\lambda_{i}\right)$ dan vektor eigen $\left(e_{i}\right)$ dari matriks sebaran antar-kelas dan pilih nilai eigen yang tidak bernilai nol.

$$
\left(\Phi_{b} \Phi_{b}^{T}\right)\left(\Phi_{b} e_{i}\right)=\lambda_{i}\left(\Phi_{b} e_{i}\right)
$$




$$
v_{i}=\Phi_{b} e_{i}
$$

6. Cari vektor eigen dari nilai eigen yang tidak bernilai nol dari matriks sebaran antar-kelas.

$$
E_{m}=\left[e_{1}, e_{2}, \cdots, e_{m}\right]
$$

7. Hitung sebanyak $m$ vektor eigen dan nilai eigen yang paling signifikan dari matriks sebaran antar-kelas.

$$
\begin{gathered}
U_{m}=\Phi_{b} E_{m} \\
\Lambda_{b}=U_{m}^{T} \hat{S}_{B T W} U_{m}
\end{gathered}
$$

8. Cari matriks $\mathrm{H}$.

$$
H=U_{m} \Lambda_{b}^{-1 / 2}
$$

9. Hitung vektor eigen dari matriks sebaran dalam-kelas dengan nilai eigen yang diurutkan.

$$
P=H^{T} S_{W T H} H
$$

10. Pilih sebanyak $M(M \leq m)$ buah vektor eigen dan nilai eigen yang pertama dari $\mathrm{P}$. Misalkan $P_{M}$ adalah vektor eigen yang dipilih dan $\Lambda_{w}$ adalah nilai eigennya.

11. Hitung nilai ciri dari matriks sebaran dalam-kelas

$$
\Psi=H P_{M}\left(\eta I+\Lambda_{w}\right)^{-1 / 2}
$$

\section{Hasil Simulasi dan Analisis}

Simulasi diawali dengan menentukan besarnya threshold atau nilai batas yang akan digunakan untuk proses klasifikasi identitas pada sistem pengenalan wajah. Citra wajah yang digunakan dalam simulasi diambil dari Database Face Recognition Data, Database Mahasiswa Maranatha, serta kombinasi dari keduanya.

Setiap database yang digunakan, masing-masing individu dalam kondisi yang berbeda-beda, seperti pose, pencahayaan, penggunaan aksesoris kacamata, dan lain sebagainya. Untuk setiap database dilakukan pengujian untuk dua kondisi. Untuk kondisi pertama jumlah citra wajah per orang hanya ada satu dalam tahap pelatihan. Sedangkan dalam kondisi kedua, dalam tahap pelatihan jumlah citra wajah per orang ada dua. Setiap citra wajah yang dipilih dalam tahap pelatihan untuk tiap orang dipilih secara acak.

Selain itu, citra wajah baik untuk pelatihan maupun dalam pengujian diatur sedemikian rupa sehingga dimensinya sama, yaitu 50×50 piksel, dimana citra wajah semula adalah citra wajah berwarna (true color/24 bit), tetapi sebelum dilakukan ekstraksi ciri citra wajah diubah menjadi citra wajah grayscale (8 bit). Akurasi pengenalan dihitung sebagai berikut :

$$
\% \text { akurasi }=\frac{\text { Jumlah citra wajah uji yangidentitasny a dikenali benar }}{\text { Jumlah total citra wajah yang diuji }} \times 100 \%
$$


Gambar 3 dan Gambar 4 berturut-turut merupakan sampel citra wajah untuk masingmasing database.
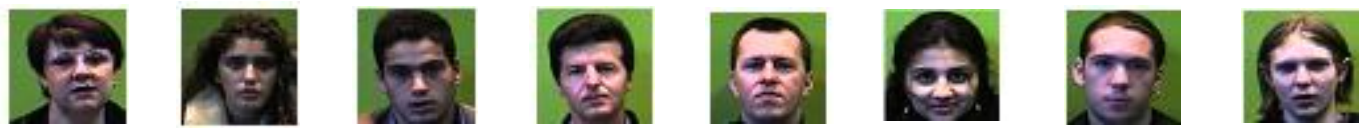

Gambar 3. Sampel Citra Wajah untuk Database Face Recognition Data
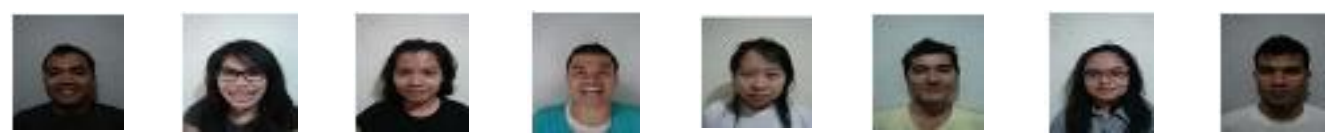

Gambar 4. Sampel Citra Wajah untuk Database Mahasiswa Maranatha

Tabel 1 menyajikan hasil simulasi (\% akurasi) untuk kedua kondisi dari masing-masing database, sedangkan Tabel 2 untuk kombinasi dari keduanya.

Tabel 1. Akurasi pengenalan untuk masing-masing database

\begin{tabular}{|c|c|c|}
\hline Katabase & Pendisi & Kedua \\
\hline Database Face Recognition Data & $86,11 \%$ & $75,92 \%$ \\
\hline Database Mahasiswa Maranatha & $85,41 \%$ & $81,25 \%$ \\
\hline
\end{tabular}

Tabel 2. Akurasi pengenalan untuk kombinasi kedua database

\begin{tabular}{|c|c|c|}
\hline Katabase & Pertama & Kedua \\
\hline Kombinasi kedua database & $75 \%$ & $90 \%$ \\
\hline
\end{tabular}

Dari Tabel 1 dapat dilihat bahwa untuk setiap database, maka akurasi pengenalan untuk kondisi pertama lebih baik daripada kondisi kedua. Kondisi pertama adalah kondisi mewakili persoalan SSS. Dari hasil simulasi ini terbukti bahwa teknik DF-LDA mampu untuk mengenali identitas wajah lebih baik jika jumlah sampel citra wajah yang ada dalam proses pelatihan lebih sedikit.

Tetapi dari hasil simulasi yang terlihat di dalam Tabel 2 terlihat sepertinya hasil ini bertentangan dengan hasil pada Tabel 1. Hal ini mungkin disebabkan oleh penggabungan citra wajah dari database yang berbeda menjadi faktor lain yang dapat mempengaruhi akurasi pengenalan karena skenario untuk memperoleh citra wajah untuk kedua database berbeda (misal: dalam Database Face Recognition Data jenis ras dan warna kulit dari orang yang dipilih lebih bervariasi dibandingkan Database Mahasiswa Maranatha).

\section{Kesimpulan}

Telah dilakukan simulasi pengenalan wajah dengan menggunakan teknik DF-LDA terhadap dua database wajah yang berbeda. Dari hasil simulasi dapat disimpulkan bahwa teknik DF-LDA dapat memperbaiki akurasi pengenalan wajah untuk persoalan SSS jika database wajah diproses secara terpisah.

\section{Daftar Pustaka}

[1] Stan Z. Li and Anil J. Kain, "Handbook of Face Recognition", Springer-Verlag London Limited, 2011.

[2] Hoi, Hyun., Kim, James., “Survey Paper: Face Detection And Face Recognition”. 
[3] Nilsson, Mikael, Jorgen Nordberg, and Ingvar Claesson. (2006). Face Detection Using Local SMQT Features and Split Up Snow Classifier. Blekinge Institute of Technology, School of Engineering, Department of Signal Processing.

[4] Nilsson, Mikael, Mattias Dahl, and Ingvar Claesson. The Successive Mean Quatization Transform. IEEE International Conference on Acoustics, Speech, and Signal Processing (ICASSP), March 2005, Vol. 4, pp. 429 - 432.

[5] Juwei Lu, Konstantinos N. Plataniotis, and Anastasios N. Venetsanopoulos, Face Recognition using LDA-Based Algorithms, IEEE Transactions on Neural Networks, Volume 14, No. 1, January 2003.

[6] Belhumeur, Peter N., Hespana, Joao P., David J. Kriegman, “Eigenfaces vs. Fisherfaces: Recognition Using Class Specific Linear Projection", IEEE Transaction On Pattern Analysis And Machine Inteligence, Vol. 19, No. 7, Juli 1997.

[7] H. Yu and J. Yang, "A direct LDA algorithm for high-dimensional data with application to face recognition," Pattern Recognition, vol. 34, pp.2067-2070, 2001.

[8] L.-F. Chen, H.-Y. Mark Liao, M-.T. Ko, J.-C. Lin, and G.-J. Yu, "A new LDA-based face recognition system which can solve the small sample size problem," Pattern Recognition, vol. 33, pp. 1713-1726, 2000.

[9] R. Lotlikar and R. Kothari, "Fractional-step dimensionality reduction," IEEE Trans. Pattern Anal. Machine Intell., vol. 22, pp. 623-627, June 2000.

[10]Yambor, Wendy S., "Analysis of PCA-Based And Fisher Discriminant-Based Image Recognition Algorithms", Computer Science Department, Colorado State University, Colorado. 